\title{
The Early Modern Genre of Cabinet in the Heritage of French Erudites
}

\section{E. A. Terenteva}

For citation: Terenteva E. A. The Early Modern Genre of Cabinet in the Heritage of French Erudites. Vestnik of Saint Petersburg University. History, 2018, vol. 63, issue 1, pp. 148-157. https://doi. org/10.21638/11701/spbu02.2018.110

The Renaissance era gave birth to a new phenomenon in the European intellectual culture the phenomenon of the cabinet of curiosities. Simultaneously, a new genre of the same name the genre of cabinet - emerged in the Renaissance literature. Though not too popular, it assumed different forms under the pen of different authors. In France its usage was mostly connected with the erudite intellectual movement that had been formed during the reign of Francis I and flourished in the second half of the sixteenth and the first half of the seventeenth centuries. Interesting variants of the genre were provided by two prominent authors of the epoch - an Arras clergyman Guillaume Gazet (1554-1612) and the future French royal historiographer André Duchesne (1584-1640). Despite the difference between their social status and professions, both Gazet and Duchesne belonged to the French erudite movement. Having practically identical titles, "Cabinet of ladies" ("Cabinet des dames"), their works were published almost concurrently at the beginning of the seventeenth century and demonstrate two patterns of using the genre in the erudite intellectual circle. One of these patterns may be characterized as pure erudite, or antiquarian; the other - as ethical, or moralistic. The peculiar use of the genre of cabinet in the French intellectual circles enables to emphasize certain distinguishing features of the French erudite movement in general, as well as to outline the specific features of the intellectual life of the French society in the Early Modern epoch.

Keywords: erudites, historical writing, historical genre, cabinet, Early Modern France, André Duchesne, Guillaume Gazet.

\section{Жанр кабинета в наследии французских эрудитов раннего Нового времени}

\section{Е. А. Терентьева}

Для цитирования: Terenteva E. A. The Early Modern Genre of Cabinet in the Heritage of French Erudites // Вестник Санкт-Петербургского университета. История. 2018. Т. 63. Вып. 1. С. 148-157. https://doi.org/10.21638/11701/spbu02.2018.110

Эпоха Возрождения породила новое явление в европейской интеллектуальной культуре - феномен кабинета редкостей. Одновременно в ренессансной литературе возник одноименный жанр - жанр кабинета. Не будучи, впрочем, слишком популярным, под

Terenteva Ekaterina A. - PhD in History, Associate Professor, St. Petersburg State University of Telecommunication (SPBGUT), 22-1, pr. Bolshevikov, St. Petersburg, 193232, Russian Federation; e.a.terenteva@bk.ru

Терентьева Екатерина Анатольевна - канд. ист. наук, доц., Санкт-Петербургский государственный университет телекоммуникаций, Российская Федерация, 193232, Санкт-Петербург, пр. Большевиков, 22 корп. 1; e.a.terenteva@bk.ru

() Санкт-Петербургский государственный университет, 2018 
пером разных авторов он принимал различные формы. Во Франции к нему прибегали преимущественно представители эрудитского интеллектуального течения, которое возникло во времена правления Франциска I и достигло расцвета во второй половине XVI - первой половине XVII в. Любопытные варианты трудов указанного жанра вышли из-под пера двух выдающихся авторов той эпохи - аррасского клирика Гийома Газе (1554-1612) и будущего королевского историографа Андре Дюшена (1584-1640). Несмотря на разницу в социальном положении и профессии, и Газе, и Дюшен принадлежали к французскому эрудитскому течению. Их работы, опубликованные почти одновременно, в начале XVII в., под практически одинаковыми заглавиями - «Кабинет дам» - демонстрируют два пути использования жанра в интеллектуальных кругах эпохи. Один из них можно обозначить как чисто эрудитский, или антикварный, второй - как этический, или моралистский. Специфика использования жанра кабинета французскими интеллектуалами позволяет подчеркнуть как определенные характерные черты французского эрудитского течения, так и особенности интеллектуальной жизни французского общества в раннее Новое время в целом.

Ключевые слова: эрудиты, историописание, исторический жанр, кабинет, Франция раннего Нового времени, Гильом Газе, Андре Дюшен.

In the Early Modern epoch Europe saw an impressive rise of both humanities and exact sciences. However, by the beginning of the scientific revolution the borders between different fields of knowledge had been far from becoming impenetrable. Such integrity concerned in particular the humanities, and thus history, philology, moral philosophy, law, political and social thought mixed in the writings of Early Modern scholars in different proportions. Furthermore, even the belles-lettres were not considered as an area strictly isolated from the studies and scholarship; for example, literature and poetry were often blended with history in the minds of contemporaries ${ }^{1}$. Combining scholarship with creation was a usual practice in the European intellectual circles in the sixteenth and seventeenth centuries.

A vivid evidence of the described processes is provided by the intellectual movement of European erudites and antiquarians ${ }^{2}$. These two denominations were used simultaneously with almost the same meaning, having specific affective evaluations in different countries ${ }^{3}$. Breaking with the tradition of medieval political histories erudites and antiquarians proceeded to studying the problems of the origins and history of peoples, laws, institutes, titles, customs and arts; they addressed the issues of coats of arms, discussed and elaborated on the matters of etymology, genealogy and philology at the same time. They used to deal with anything connected with the ethno-cultural peculiarity of their own countries.

In France during the sixteenth and seventeenth centuries the term "erudite" had been used for designation of an intellectual of the mentioned activities; the term "antiquary" was less common. In 1679 Jacob Spon defined their sphere of interests as "the knowledge about what the ancients wished to convey to their descendants about their religion,

${ }^{1}$ Even at the end of the $18^{\text {th }}$ century the novel "Astrée" by Honoré d'Urfé, as well as "Princess of Cleves" by Madam de Lafayette were classified as histories. See, for example: Histoire // Dictionnaire Universel François et Latin, vulgairement appelé Dictionnaire de Trévoux. Nouvelle edition, corrigée et considerablement augmentée. Vol. 4. Paris, 1771. P. 840.

2 See, for example: Palamarchuk A., Fedorov S. Antikvarnyi diskurs v rannestjuartovskoi Anglii. St. Petersburg, 2013.

${ }^{3}$ See, for example: Fyodorov S. Consuming splendor: Society and culture in seventeenth-century England. By Levy Peck Linda // The Historical Journal. 2005. 51(1). P.277-279. 
their sciences, their history, their policy through original monuments which they had left to us" ${ }^{4}$, i.e. the antiquities. The term "antiquities" included material remains of the past (coins, ruins, manuscripts, pictures, inscriptions, statues, medals, seals) and non-material substances such as institutes, offices, customs and titles.

Apart from the new subject area, the erudites and antiquarians developed a new research methodology. Changing the comprehension of historical evidence, they started using new types of original sources, such as archaeological material, and changed the practice of utilization of the written sources. Changes in historical knowledge in Early Modern Europe turned out to be so deep that in the third quarter of the twentieth century a pleiad of historians didn't hesitate to name these changes a historical revolution ${ }^{5}$.

The special interest in vernacular past, vernacular history was characteristic of the European societies at the time. This interest, being a consequence of both intellectual and social processes, gave birth to new historical genres and revived already existing ones, such as chorographies, genealogies and genealogical histories, etc., which were used by the new "history writers" - the erudites. In this intellectual circle a specific genre came into existence - the genre of cabinet.

At the same time all the foregoing traits of Early Modern intellectual activities (both thematic and methodological) manifested themselves in a new phenomenon in the life of Renaissance Europe - the phenomenon of the cabinet of curiosities. A sort of museum emerged. It received different names - cabinet of curiosities, cabinet of antiquities, Kunstkammer - and got an incredible popularity in sixteenth and seventeenth century Europe. The Renaissance brought the rise of lively interest not only in monuments of the past but also in pieces of art, wonders of nature (which may be characterized as objects relating to natural history) and exotic ethnographical items as well. Such encyclopedic collections at the same time demonstrated the high degree of integrity of European knowledge, the forming of a new taste for empiricism and rationalism and a new passion for collecting, but also were illustrative of the interest in antiquities.

One of the sixteenth century erudites, Claude Fauchet, wrote in 1581 that interest in the antiquity was then so vivid that most of the well-to-do people, "however ignorant they were", wished to represent it as far as possible: "some with books and medals, others with all the pieces they are able to recover"6. He also mentioned the passion of the "grand men" to decorate their cabinets with the material remains of the past ${ }^{7}$.

Although in the past several decades a multitude of researches has been published in the field of the intellectual history and, in particular, concerning the French erudite movement, little attention has been paid to the different genres in the Renaissance scientific literature, and no research has been found that surveyed the Early modern erudite genre of cabinet. On the other hand, the notion of cabinet has been analyzed in the sense of a special place for keeping collections. At the beginning of the twenty-first century a special

${ }^{4}$ Spon J. Réponse à la critique publiée par M. Guillet, Sur le Voyage de Grece de Iacob Spon. Avec quatre Lettres sur le mesme sujet, le Journal d'Angleterre du sieur Vernon, et la Liste des erreurs commises par M. Guillet dans son Athenes ancienne et nouvelle. Lyon, 1679. P. 63.

${ }^{5}$ Preston J. H. Was there an Historical Revolution? // Journal of the History of Ideas. 1977. Vol.38, no. 2 (April - June). P. 353.

${ }^{6}$ Fauchet $C$. Recueil de l'origine de la langue et poesie françoise, ryme et romans. Plus les noms et sommaire des œuvres de CXXVII. poetes François, vivans avant l’an M. CCC. Paris, 1581. P. a.ij.

7 Ibid. 
interest has arisen in the cabinets of curiosities as a sort of first museums, i. e. as a page of history of collecting, particularly in the French science ${ }^{8}$.

And yet the analysis of the use of the genre in France enables to emphasize certain distinguishing features of the French erudite movement in general, as well as to outline the specific traits of the intellectual life of the French society in the context of the culture of curiosity in Renaissance and Early Modern Europe.

The genre of cabinet seems to have emerged simultaneously with the coming into existence of the phenomenon of the cabinet of curiosities and to have been typologically very close to it. The genre didn't gain wide popularity in the French intellectual circles. The works with such titles published in France in the sixteenth and seventeenth centuries may be easily quantified. However, the genre assumed specific forms under the pen of different authors.

Before proceeding to the classification and characterization of such works it seems useful to resort to the dictionaries of the epoch for the definition of the term "cabinet". The widely known dictionary of Furétière published in 1690 (at the end of the period in question, after the publication of the most part of the works analyzed in the present article) gave seven main meanings of the word "cabinet" in the following sequence:

1) the most isolated place in the gala apartment of the palace;

2) a small place in a private house, often formed not with a wall but with a partition, intended for studying or for keeping precious objects;

3) a sort of a small pavilion in a garden;

4) a cloakroom or a toilet;

5) a store where curiosities of all kinds are kept, sold and changed; these may be ancient pieces, medals, paintings, shells and other curiosities of nature and objects of virtu. The dictionary of Furétière also distinguished a particular case of such use of the word: "They say that the King and some of the nobles have Cabinets of books, of arms, of medals - i. e. places where these objects are stowed, or the stored objects themselves".

6) a sideboard with many drawers;

7) an element of the machinery of the absolutist state - the Royal Cabinet (Cabinet du Roy) ${ }^{9}$.

8 The Origins of Museums: The Cabinet of Curiosities in Sixteenth- and Seventeenth-Century Europe / ed. by Oliver Impey and Arthur MacGregor. [S.1.], 2001; Schnapper A. Le géant, la licorne et la tulipe. Les cabinets de curiosités en France au XVIIe siècle. Paris, 2012; Schlosser J. von. Les Cabinets d'art et de merveilles de la Renaissance tardive. Une contribution à l'histoire du collectionnisme. Paris, 2012; Pomian K. Collectionneurs, amateurs et curieux. Paris; Venise, 1987; Mauriès P. Cabinets de curiosités. Paris, 2002; Martin P., Moncond'Huy D. Curiosité et cabinets de curiosités. Neuilly, 2004; Marcoux C. N. Objets d'échanges et regards croisés, entre l'Afrique de la Côte-de-l'Or et l'Europe des Curiosités $\left(\mathrm{XVI}^{\mathrm{e}}-\mathrm{XVIII}^{\mathrm{e}}\right.$ siècles). Clermont-Ferrand, 2015; Impey O., Macgregor A. The origins of museums: the cabinet of curiosities in sixteenth and seventeenth century Europe. New York, 2001; Gargam A. Savoirs mondains, savoirs savants: les femmes et leurs cabinets de curiosités au siècle des Lumières // Genre \& Histoire [En ligne]. 2009. 5. Automne. URL: http://genrehistoire.revues.org/899 (accessed 28.10.2017); Falguières P. Les Chambres des merveilles. Paris, 2003; Davenne Ch. Modernité du Cabinet de Curiosités. Paris, 2004; Arnold K. Cabinets for the curious: looking back at early English museums. Burlington, 2006.

9 Dictionnaire Universel, Contenant generalement les Mots François tant vieux que modernes, \& les Termes de toutes les Sciences et des Arts. Recueilli \& compilé par seu Messire Antoine Furetiere, Abbé de Chalivoy, de l’Academie Françoise. Vol. 1. La Haye; Rotterdam, 1690. P. 300. 
Later dictionaries and encyclopedias omitted several meanings from the above list ${ }^{10}$. But the most popular and widespread denotation of the term "cabinet" still seemed to be "a specific place" (in landscape architecture, interior and closely related to it meaning of an article of furniture).

Thus, we don't see any mentioning of the use of the word "cabinet" in connection with the writings of any kind. It appears interesting that the word "cabinet" as a literary genre has never been mentioned in the dictionaries of the Modern times.

However, in effect the genre of cabinet did exist. In sixteenth and seventeenth century France there emerged quite a variety of works in this genre, of which the Bibliothèque nationale de France has a quiet solid collection. They can be divided in four groups according to their subject areas.

The works describing the contents of some real cabinet, often of a politician or a man of letters, but sometimes of some private individual, form the first group of such papers ${ }^{11}$. Strictly speaking, not all the works of this group are entitled as "cabinets"; some titles contain such expressions as "the inventory of the cabinet" or "something got from the cabinet of..."12. There are two types of such works: the contents of the cabinet in question could be either material (antiquities or virtu) or manuscript (i.e. documents, letters, memoirs). The examples of the first case are numerous and include "The cabinet of the library of Saint-Genevieve". The example of the second one is "The Cabinet of Louis XI"13 for official persons and "Reprimand to the newly married... found in the cabinet of a woman after her death" 14 for private persons.

In the titles of the second large group of works in the genre of cabinet this term is used as a synonym of an anthology or collection. This group is connected with the belles-lettres

${ }_{10}$ Dictionnaire Universel François et Latin, vulgairement appelé Dictionnaire de Trévoux. Nouvelle edition, corrigée et considerablement augmentée. Paris, 1771. Vol 2. P. 488-493.

${ }^{11}$ Du Molinet Claude. Le cabinet de la bibliotheque de Sainte Genevieve. Divisé en deux parties. Paris, 1642, 1692; Le cabinet des beaux-arts, ou Recueil d' estampes gravées d' après les tableaux d'un plafond où les beaux-arts sontre présentés. Avec l'explication de ces mêmes tableaux. Paris, 1690; L’inventaire du cabinet du sieur Toussaint Lauthier d'Aix en Provence, consistant en anciennes medailles, pierres precieuses, gravées tant en creux qu'en bas relief; statuës, tableaux, coquilles \& plusieurs autres choses naturelles \& artificielles. Aix, 1663; Spon Jacob. Discours sur une pièce antique et curieuse du cabinet de Jacob Spon. Representée dans la planche suivante. Lyon, 1674; Barnaud Nicolas, Froumenteau Nicolas. Le cabinet du roy de France, dans lequel il y a trois perles précieuses d'inestimable valeur: par le moyen desquelles Sa Majesté s'en va le premier monarque du monde \& ses sujets du tout soulagez. [S.1.], 1581; Mémoires pour servir à l'histoire, tirés du cabinet de messire Léon Du Chastelier-Barlot depuis l'an 1596 jusques en 1636. Fontenay, 1643; Le Cabinet de Louis XI, contenant plusieurs fragments, lettres, missives, etc., de ce monarque et autres pièces curieuses / ed. by l' Hermite de Soliers, dit Tristan. Paris, 1661 (publication - Paris: G. Quinet, 1681. 124 p.); Remontrance aux nouveaux mariéz et mariées, et ceux qui désirent de l'efere. Ensemble pour connoitre les humeurs des femmes, trouvées dans le cabinet d'une femme après sa mort. Tours, 1644. Pièce; La cresme des bons vers: triez du meslange et cabinet des sieurs de Ronsard, du Perron, de Malerbe, de Sigongnes, de Lingendes, Motin, Maynard, de Bellon, St Urfe, Theophile et autres. Lyon, 1622; Le grand miroir des financiers tiré du cabinet des Curiositez, du Deffunct Cardinal de Richelieu, où l'on void: I. L'Homme d'Estat en matieres d'Interests. II.L'ordre de manier les finances. III. Les moyens de faire profiter l'argent du Roy, l'avancement de la fortune des Intendants, \& son declin. IV. Le discernement des Maltotiers d'avec les Officiers legitime de l'Espargne. V. Discours necessaire à tous Gens d'affaires \& de finances. Paris, 1652.

12 L'inventaire du cabinet du sieur Toussaint Lauthier d'Aix en Provence, consistant en anciennes medailles, pierres precieuses, gravées tant en creux qu’en bas relief; statuës, tableaux, coquilles \& plusieurs autres choses naturelles \& artificielles. Aix, 1663.

${ }^{13}$ Le Cabinet de Louis XI...

14 Remontrance aux nouveaux mariéz et mariées, et ceux qui désirent de l’efere. Ensemble pour connoitre les humeurs des femmes, trouvées dans le cabinet d'une femme après sa mort. Tours, 1644. 
and consists of anthologies of poetry of different kinds: either the selected works of the French poets or thematic collections of songs ${ }^{15}$.

The third group consists of the "pure erudite" cabinets which contain virtual collections of different kinds ${ }^{16}$ - from various problems of navigation ${ }^{17}$ to the erudite research of the nobility ${ }^{18}$.

Finally, the last, fourth group, is formed of the so-called "mystical cabinets" - works of moralistic character containing morals and being congeneric with both didactic and religious literature of the epoch ${ }^{19}$.

${ }^{15}$ Le Gendre Marie. Cabinet des saines affections. Dernière édition augmentée de XII Discours et quelques stances sur le mesme sujet. Par Madame de Rivery. Paris, 1595; Franeau Jean. Jardin d'hyver, ou Cabinet des fleurs, contenant en XXVI élégies les plus rares et signalez fleurons des plus fleurissans parterres. Douay, 1616.; Contant Paul. Le Jardinet Cabinet poétique de Paul Contant, apoticaire de Poictiers. Poictiers, 1609; Carneau Etienne. La piece de cabinet, dédiée aux poëtes du temps. Paris, 1648; Régnier Mathurin: 1) Le cabinet satyrique ou recueil parfaict des vers piquants et gaillards de ce temps. Nouvelle édition. Paris, 1613; 2) Le Cabinet satyrique, ou Recueil parfaict des vers piquans et gaillards de ce temps, tiré des secrets cabinets des sieurs de Sigogne, Régnier, Motin, Berthelot, Maynard et autres des plus signalez poètes de ce siècle. Paris, 1618; Nouveau cabinet des Muses, ou l'Eslite des plus belles poësies de ce temps / ed. by De Lamathe. Paris, 1658; Le Parnasse des muses, ou Recueil des plus belles chansons à danser. Recherchées dans le cabinet des plus excellens poëtes de ce temps. Dedié aux belles dames. Deuxiesme edition. Paris, 1628; Le cabinet des Muses, ou recueil des plus beaux vers de ce temps. Rouen, 1619; Nouveau cabinet des muses ou l'eslite des plus belles poésies de ce temps / ed. by de La Mothe. Paris, 1658; Le nouveau cabinet des muses gaillardes. [S.1.], 1665; Le Cabinet des plus beles chansons nouvelles, tant de l'amourque de la guerre, recueillies des plus excellens poètes françois de ce temps et autres. Lyon, 1592; Le cabinet des plus belles chansons. Lyon, 1592; Le petit cabinet des chansons nouvelles et amoureuses. Recueillies de divers autheurs. Lyon, 1614.

16 Pontier Gédéon: 1) Le Cabinet ou La bibliothèque des grands, contenant des remarques et recherches surtous les états souverains, et plusieurs mémoires de ce tems bien particuliers et très curieux. Histoire, chronologie, topographie, hydrographie, politique, armes, devises, merveilles et autres choses nobles. T. I. Paris, 1682; 2) La Continuation du Cabinet des grands, contenant les devises des empereurs d'Orient et d'Occident, expliquées et enrichies de sentences, maxims d'État et de traits d'histoire; les prophéties de S. Malachie touchant les papes depuis Célestin II jusquà la venue de l'Antechrist, et plusieurs choses remarquables de ce tems arrivées en plusieurs cours et ailleurs. Avec la réponse à la critique du Journal des savants de Lipsic sur les deux premiers tomes du Cabinet des grands. Paris, 1689; Waghenaer Lucas Janszoon. Thrésorerie ou Cabinet de la routte marinesque: contenant la description de l'entière navigation et cours de la Mer septentrionale d'Allemaigne, d'Angleterre et d'Escosse, France et Espaigne / nouvellement mis en lumière par l'expert et renommé pilote Lucas Jansz WagenaerAuxquelles sont adjoutéz certains discours et véritables récits comme on peult navigant environner la terre. Item cincq moyens, routtes ou erres de mer pour venir en China, un traicté de la variation du quadran de mer, certaines questions concernant la navigation, le commerce des marchandises en l'Inde orientale et quelles denrées on apporte de là en ces pays par deça. Calais, 1601; Du Chesne A. Figures Mystiques du Riche et precieux Cabinet des Dames ou sont representées au Vif, tant les Beatez Parures et Pompres du Corps Feminin: que les Perfections, Ornemens et Atours Spirituels' de l'Ame. Paris , 1605; Assignies Jean d'. Cabinet des choses plus signalées advenues au sacré ordre de Cysteau, signamment des vies et histoires de plusieurs saints prélats d'iceluy, recueillies de divers livres tant escrits qu'imprimez et mis en langage vulgaire, par F. Jan d'Assignies. Douai, 1598; Camus Jean-Pierre. Le Cabinet historique, remply d'histoires veritables, arriveés tant de dans que dehors le royaume, avec les moralitez. Paris, 1668; Le Comte Florent. Cabinet des singularitez d'architecture, peinture, sculpture et graveure, ou Introduction à la connoissance des plus beaux arts figuré sous les tableaux, les statues et les estampes. In 3 vols. Paris, 1699-1700; Monnier I.-L. Le Cabinet secret des grands préservatifs et spécifiques propres, contre la peste, fièvres pestilentielles, pourpres, petites vérolles, et toutes sortes de maladies contagieuses. Paris, 1666.

17 Waghenaer Lucas Janszoon. Thrésorerie ou Cabinet de la routte marinesque...

18 Pontier Gédéon: 1) Le Cabinet ou La bibliothèque des grands...; 2) La Continuation du Cabinet des grands ...

19 Saint-Samson Jean de. Le cabinet mystique; contenant les regles de la conduite des ames religieuses. Divisé en deux parties. 1. La conduite des novices. 2. Regles pour discerner les divers esprits, de grace, de nature, \& du Demon. Rennes, 1655; Blois Louis de. Cabinet de lâme fidelle, où sont contenus le Miroir spirituel, la Bague spirituelle, la Couronne spirituelle, le Coffret spirituel. Escrit par Loys de Blois, abbé du 
Some works unite the traits of two or more groups, being, for example, a collection ("cabinet") of poems and at the same time a part of a material cabinet of some person ${ }^{20}$.

Despite the medium or even little popularity of the genre of cabinet in France in the sixteenth and seventeenth centuries, the titles of these works (apart from the literary ones) were rather diverse. However, two papers stand out from the lists of works of the third and fourth groups by their similar titles including the expression "the cabinet of ladies". These are "The Cabinet of ladies containing the spiritual ornament of the Christian wife, girl and widow; and also the Cabinet of the virgin devoted to God by the vow of chastity. With a Historic Calendar of Saint and virtuous ladies. Dedicated to ladies-in-waiting of the Serene Infanta of Spain" by Guillaume Gazet ${ }^{21}$ and "The mystical figures of the rich and precious Cabinet of ladies where the beauties, finery and adornments of the feminine body as well as the spiritual perfections, ornaments and attires of the soul are vividly represented"22 by André Duchesne. Besides the likeness of titles, the two works were published almost simultaneously, in the first decade of the seventeenth century. Hence, the comparison of these incarnations of the genre of cabinet is especially interesting.

André Duchesne (1584-1640) was called by his successors "the father of the French history", and he surely deserved this title. He started his erudite career rather early (the first publication dated from 1602). Later he got the office of the royal geographer and historiographer, published more than thirty works and left dozens of unpublished papers on various historical and geographical subjects, from genealogical histories and the history of French cardinals to the description of antiquities of the French kingdom. The investigated subjects as well as the specific methods of research characterize Duchesne as an erudite ${ }^{23}$.

Guillaume Gazet (1554-1612) seems to be a stranger in the modern historiography, not having become a subject of interest to scholars yet. Born in Arras in 1554, he was appointed parish priest of the church of Sainte-Marie-Madeleine in Arras around 1580, and later combined this office with the office of a canon of the collegiate church of Saint-Pierre

monastère de Liessies. Traduit du latin en français par Jacques Froye, religieux de l'Ordre de Saint-Benoist à Liessies. Nouvellement reveu et corrigé mesme quant au langaige. Douay, 1596; Gazet G. Le Cabinet des dames: contenant l'ornement spirituel de la femme, fille, \& Vefue Chrestienne. Plus Le Cabinet de la Vierge consacree à Dieu par le voeu de Chasteté. Avec un Calendrier Historial des Sainctes \& vertueuses Dames. Dedié aux Dames d'honneur de la Serenissime Infante d'Espagne etc. Par M. Guill. Gazet Chanoine d'Aire, \& Pasteur de S. Marie Magdelaine à Arras. Arras, 1602; Niclot Simon. Le petit cabinet des vierges et ames chastes. Composé des sentences \& pensées tant de la Ste. Ecriture, que des Saints et anciens Peres de l'Eglise. Par le R. P. Simon Niclot, religieux Minime. Reims, 1649; Mougne Roberte (veuve de JérômeBelon). Le Cabinet de la vefve chrestienne, contenant prières et méditations sur divers sujets de l'Escriture saincte. Sedan, 1648; Le Jau Jean. Cabinet royal de l'espoux meublé par son espouse, avec le Jardin spirituel, divisé en huict discours, auquel est adjoustée l'Oraison funèbre. Évreux, 1631.

${ }^{20}$ Régnier Mathurin. Le Cabinet satyrique...

${ }^{21}$ Gazet G. Le Cabinet des dames: contenant lornement spirituel de la femme, fille, \& Vefue Chrestienne. Plus Le Cabinet de la Vierge consacree à Dieu par le voeu de Chasteté...

${ }_{22} \mathrm{Du}$ Chesne A. Figures Mystiques du Riche et precieux Cabinet des Dames ou sont representées au Vif...

${ }^{23}$ For more information on André Duchesne see: Terenteva E. A., Palamarchuk A. A. Rozhdenie natsional'nogo istoriopisaniya vo Frantsii: trudy i istoricheskiy metod Andre Dyushena // Vestnik of Saint-Petersburg University. History. 2015. Issue 2. P. 80-92; Pronina E. A.: 1) Istoriya na sluzhbe u korolya i kardinala: otets i syn Dyusheny // Klio. 2011. N 2 (53). P. 39-43; 2) "Ottsy istorii" Frantsii i Velikobritanii: Andre Dyushen i Uilyam Kemden ( $\mathrm{k}$ voprosu o zarozhdenii natsional'nogo istoriopisaniya v stranakh Evropy rannego novogo vremeni) // Klio. 2012. N 2 (62). P. 86-88. 
in Aire-sur-la-Lys ${ }^{24}$. Since 1589 up to the end of his life he had been publishing different works as an author, editor or translator. Surely his priesthood had an impact on his heritage adding a spiritual shade to it. Nevertheless, his sphere of interest characterizes him as an erudite, as well as the French language of his works enables to ascribe him to the French erudite circle despite the official Spanish status of Arras at that time. The list of his works shows his connection with the French erudite movement of the epoch, because apart from several purely ecclesiastical writings he mostly dealt with quite "erudite" problems ${ }^{25}$. Thus, the two "cabinets" may be regarded as creations by the members of a common intellectual circle.

As for their form, in both cases the material was organized systematically, which was characteristic of most erudite works. The tables of contents of both works could remind the reader the structure of a cabinet-bureau: "The general enumeration of the riches locked up in this present Cabinet of ladies" (Duchesne's) and "Table of contents of the cabinet of wife; of widow; of girl; of the veiled nun" (Gazet's). Nevertheless, in terms of themes they don't bear resemblance.

Both works were connected with the sphere of morality, and their titles emphasized the ethical aspect of the contents. However, as it could have been anticipated, the work of a secular writer, A. Duchesne, resembles a sermon far less than the text written by a clergyman. Although the title of Duchesne's cabinet, in contrast to Gazet's, contains the term "mystical", in fact it turned out to be much worldlier.

History and morality had been closely intertwined in the mind of a European in the Early Modern epoch. For a long time studying history had been highly recommended for the education of the nobles of both sexes in order to cultivate moral principles and to instill self-perfection ${ }^{26}$. In addition, we can conclude that Duchesne had made the most of this phenomenon, basing his "mystic cabinet" on the didactic stories from the past and thus trying to emphasize the superiority of the spiritual beauty over the temporal one.

While Gazet's work aimed at the regulation of women's behavior and was based on the Christian moral philosophy, Duchesne's "cabinet" pursued another goal. Despite the declarations and specific rhetoric (we shouldn't forget that the Paris theology doctors

${ }^{24}$ Niceron R. P. Mémoires pour servir à l'histoire des hommes illustres dans la république des lettres. Avec un catalogue raisonné de leurs ouvrages. T. 43. Paris; 1745. P. 271-276.

25 G. Gazet published more than a dozen of works. Most of them were of his own: Magdalis. Comoedia sacra. Douai, 1589; Chanson nouvelle pour l'heureux succez de l'armée catholicque ensemble, de la prinse des ville et chasteau de Calais. Arras, 1596; Lordre et suite des evesques et archevesques de Cambray. Arras, 1597; L'ordre des evesques d'Arras depuis la separation de l'evesché de Cambray. Arras, 1598; Lordre et suyte des evesques de Cambray et d’Arras. Arras, 1598; Briève histoire de la sacrée manne et de la sainte chandelle miraculeusement données de Dieu et religieusement conservées en la ville et cité d'Arras. Arras, 1598; Le cabinet des Dames: contenant l'ornement spirituel de la femme. Arras, 1602; Le consolateur des ames scrupvleuses. Arras, 1610; Tableaux sacrez de la Gaule Belgique. Arras, 1610; La Bibliotheque Sacree du Pays-Bas. Arras, 1610; L'Histoire ecclésiastique des Pays-Bas. Arras, 1614. G. Gazet also translated two ecclesaistical works (Androzzi Fulvio. Devot memorial des saints mysteres de la mort et passion de nostre sauveur et redempteur Jesus Christ. Arras, 1595 (reissued - Douai, 1599); Balbano Bernardino de. Le sacre mystere de la flagellation de nostre sauveur. Arras, 1595) and acted as a scientific editor (Various authors. Thesaurus precum et litaniarum. Arras, 1601; Metaphrastes Simeon. Histoire de la vie, mort, passion et miracles des saints. Arras, 1584 (reissued - Arras, 1596; Douai, 1598); Niceron R. P. Mémoires pour servir à l'histoire des hommes illustres dans la république des lettres. Avec un catalogue raisonné de leurs ouvrages. T. 43. Paris, 1745. P. 271-276.

${ }^{26}$ Bourquin L. La noblesse dans la France moderne (XVI ${ }^{\mathrm{e}}-\mathrm{XVIII}{ }^{\mathrm{e}}$ siécles). P. 115. 
approved of Duchesne's work in $1604^{27}$ ) the essence of his work concerned explaining the symbolism (though mostly spiritual), the origins and the history (Biblical, antique or barbarian) of perception of the feminine beauty, elements of costume and accessories. The advice given to the fair readers by Duchesne are not perceived as the essentials of his book - in contrast to the moralistic sentences and warnings of Gazet, who also had decorated his narrative with the examples of the ancient and medieval history.

Thus, despite the unity of genre, the similarity of titles and declared objectives, and even the similar audience (both works were devoted to noble women), the works of Duchesne and Gazet mostly demonstrated two different patterns of use of the genre of cabinet. The one chosen by Duchesne could be characterized as erudite; the one chosen by Gazet - as ethical, or moralistic. However, borders between them didn't seem impenetrable.

Thus, the genre of cabinet was not extremely widespread in Early Modern France though it can be considered as rather characteristic of the epoch and, therefore, deserves study and analysis.

The most general definition of it could be "a collection of anything that could be presented in a written form", though such works often acquired distinctive features and even could be classified in four groups. In contrast to the material cabinet of curiosities, the cabinet as a genre not only enumerated objects but also provided the reader with proper characteristics and commentaries.

A large part of the erudite and antiquarian heritage was tightly connected with the social and political processes taking place in Early Modern Europe, such as the formation of the absolute monarchies, the rise of ethno-cultural identities and the religious controversies. Nevertheless, certain fields of erudite studies still remained sufficiently autonomous from the politics. The genre of cabinet mostly demonstrates the latter trend in the erudite thought.

As for the use of new methods and the spreading rationalism of the Europeans, the particularity of the genre of cabinet emphasized the value of collecting antiquities and moreover - of systematizing material. Though Descartes reproached the contemporary researchers in the field of humanities for not having a system, this reproach might have been rejected by the erudites who had had a taste for systematizing, and the metaphor of cabinet with lots of small drawers perfectly conveyed the specificity of the erudite research.

The genre of cabinet didn't end with the Renaissance and Early Modern era. It was developed later, in the eighteenth and nineteenth centuries - there emerged a number of reviews and collected works with such titles ${ }^{28}$. The genre lost its moralistic and descriptive features and remained in the area of anthologies and collections of knowledge concerning

27 Approbation des docteurs // Du Chesne A. Figures Mystiques du Riche et precieux Cabinet des Dames ou sont representées au Vif, tant les Beatez Parures et Pompres du Corps Feminin: que les Perfections, Ornemens et Atours Spirituels' de l'Ame. Paris, 1605.

${ }^{28}$ For example: Le Cabinet des fées, ou Collection choisie des contes des fées, et autres contes merveilleux. In 8 vols. Genève; Paris, 1785-1789; Cabinet des modes, ou les modes nouvelles, décrites de manière claire et précise, et représentées par des planches en taille-douce, enluminées: ouvrage qui donne une connoissance exacte \& prompte, tant des habillemens \& parures nouvelles des personnes de l'un \& de l'autre sexe, que des nouveaux meubles de toute espèce, des nouvelles décorations, embellissemens d'appartemens, 
certain subjects. It become a usual practice in the twentieth century and hasn't come out of use up to the contemporary times, though in the sphere of pure science, to be more precise - the sphere of humanities.

\section{References}

Arnold K. Cabinets for the curious: looking back at early English museums. Burlington, Ashgate Publ., 2006, $297 \mathrm{p}$.

Berger G. Genres bâtards: roman et histoire à la fin du XVIIe siècle. Dix-septième siècle, 2002/2 (no. 215), pp. 297-305.

Bourquin L. La noblesse dans la France moderne (XVI $-X V I I I^{e}$ siécles). Paris, Belin Publ., 2002, 267 p.

Davenne Ch. Modernité du Cabinet de Curiosités. Paris: L’Harmattan Publ., 2004, 299 p.

Dear P., Shapin S. Nauchnaia revoliutsiia kak sobytie. Moscow, NLO Publ., 2015, 576 p. (In Russian)

Eco U. Evoliutsiia srednevekovoi estetiki. St. Petersburg, Azbuka-klassika Publ., 2004, 288 p., ill. (In Russian)

Eco U. Iskusstvo krasota v srednevekovoi estetike. St. Petersburg, Aleteiia Publ., 2003, 256 p. (In Russian)

Falguières P. Les Chambres des merveilles. Paris, Bayard-Centurion Publ., 2003, 140 p.

Fyodorov S. Consuming splendor: Society and culture in seventeenth-century England. By Levy Peck Linda. The Historical Journal , 2005, 51(1), pp. 277-279.

Grafton A. What was History? The Art of History in Early Modern Europe. Cambridge, Cambridge University Press, 2007, 319 p.

Grell Ch. L'histoire entre érudition et philosophie. Etude sur la connaissance historique à l'âge des Lumières. Paris, Presses Universitaires Francais, 1993, 415 p.

Marcoux C. N. Objets d'échanges et regards croisés, entre l'Afrique de la Côte-de-l'Or et l'Europe des Curiosités (XVI ${ }^{e}-X V I I I^{e}$ siècles). Clermont-Ferrand, Université Blaise Pascal Press, 2015, 132 p.

Martin P., Moncond'Huy D. Curiosité et cabinets de curiosités. Neuilly, Atlande Publ., 2004, 202 p.

Mauriès P. Cabinets de curiosités. Paris, Gallimard Publ., 2002, 259 p.

Neuschel K. B. Word of Honor: Interpreting Noble Culture in Sixteenth-Century France. New York, Cornell University Press, 1989, 223 p.

Palamarchuk A., Fedorov S. Antikvarnyi diskurs v rannestiuartovskoi Anglii. St.Petersburg, Aleteiia Publ., 2013, 210 p. (In Russian)

Parry G. The Trophies of Time. English Antiquarians of the Seventeenth century. Oxford, New York, Oxford University Press, 2007, 382 p.

Pomian K. Collectionneurs, amateurs et curieux. Paris; Venise, XVI ${ }^{\mathrm{e}}-\mathrm{XVIII}{ }^{\mathrm{e}}$ siècles Publ., Gallimard, 1987, $376 \mathrm{p}$.

Preston J. H. Was there an Historical Revolution? Journal of the History of Ideas, 1977, vol. 38, no. 2 (April June), pp. 353-364.

Pronina E. A. Istoriia na sluzhbe u korolia i kardinala: otets i syn Diusheny. Klio, 2011, no. 2 (53), pp. 39-43. (In Russian)

Pronina E. A. "Ottsy istorii" Frantsii i Velikobritanii: Andre Dyushen i Uilyam Kemden (k voprosu o zarozhdenii natsional'nogo istoriopisaniia v stranakh Evropy rannego novogo vremeni). Klio, 2012, no.2 (62), pp. 86-88. (In Russian)

Schlosser J. von. Les Cabinets d'art et de merveilles de la Renaissance tardive. Une contributionà l'histoire du collectionnisme. Paris, Macula Publ., 2012, 372 p.

Schnapper A. Le géant, la licorne et la tulipe. Les cabinets de curiosités en France au XVII siècle. Paris, Flammarion Publ., 2012, 768 p.

Terenteva E. A., Palamarchuk A. A. Rozhdenie natsional'nogo istoriopisaniia vo Frantsii: trudy i istoricheskii metod Andre Diushena. Vestnik of Saint-Petersburg University. History. 2015, issue 2, pp. 80-92. (In Russian)

Received: 14.10 .2017

Accepted: 28.12.2017

nouvelles formes de voitures, bijoux, ouvrages d’orfévrerie, \& généralement de tout ce que la mode offre de singulier, d'agréable ou d'intéressant dans tous les genres. Paris, 1785. 